\title{
AKTIVITAS ANTIOKSIDAN Fraksi n-hexan, Kloroform dan etil asetat DAUN MATOA (Pometia pinnata J.R \& G. Forst) TERHADAP DPPH (2,2-difenil-1-pikrilhidrazil)
}

\author{
Wahyu Margi Sidoretno ${ }^{1)}$ Iis Sintiyani $^{2)}$ \\ 1) D III Analis Farmasi dan makanan, FKIK Universitas Abduurab \\ J1. Riau ujung No 76 Pekanbaru Indonesia \\ email : wahyu.margi@univrab.ac.id \\ ${ }^{2)}$ D III Analis Farmasi dan makanan, FKIK Universitas Abduurab \\ Jl. Riau ujung No 76 Pekanbaru Indonesia \\ email : iis.sintiyani@univrab.ac.id
}

\begin{abstract}
Antioxidant is a matter that can neutralize free radical substances by giving one or more ptotons for the radical materials to dismiss their "un-pairs" condition. The previous study states that matoa's leaf contains some secondary metabolites of flavonoid, tannin and saponin. This research aims to determine antioxidant activity of the n-hexane, chloroform, and ethyl acetate extract of matoa's leaf on DPPH (2,2duphenyl-1- picrylhydrazyl). The activity was determined on $520 \mathrm{~nm}$ using microplate reader. The result shows that the IC50 value of the n-hexane and chloroform extract concentration of 1000; 500; 250; 125; 62.5 and $31.25 \square \mathrm{g} / \mathrm{ml}$ is 312.1238 and $100.9470 \square \mathrm{g} / \mathrm{ml}$. Moreover,

the IC50 value of the ethyl acetate concentration of $100 ; 50 ; 25 ; 12.5 ; 6.25$ and 3.125 is $12.1876 \square \mathrm{g} / \mathrm{ml}$. It can be concluded that the n-hexane extract shows a weak antioxidant activity, the chloroform extract shows a intermediate's and the ethyl acetate has a very strong antioxidant effect.
\end{abstract}

Keywords : Pometia pinnata, antioxidant, activity, DPPH, ethyl acetate.

\begin{abstract}
ABSTRAK
Antioksidan adalah senyawa yang dapat menetralkan radikal bebas dengan cara menerima atau mendonorkan satu elektron untuk menghilangkan kondisi "elektron tidak berpasangan pada radikal bebas". Diketahui daun matoa mengandung kelompok senyawa berupa flavanoid, tanin dan saponin. Tujuan dari penelitian ini adalah untuk mengetahui aktivitas antioksidan ekstrak daun matoa (Pometia pinnata J.R \& G. Forst) terhadap DPPH (2,2- difenil-1-pikrilhidrazil) pada fraksi n-heksan, klorofom dan etil asetat. Pengujian dilakukan pada panjang gelombang $520 \mathrm{~nm}$ digunakan microplate reader. Uji aktivitas antioksidan fraksi n-heksan dan klorofom menggunakan konsentrasi $1000 \mu \mathrm{g} / \mathrm{ml}, 500 \mu \mathrm{g} / \mathrm{ml}, 250 \mu \mathrm{g} / \mathrm{ml}$, $125 \mu \mathrm{g} / \mathrm{ml}, 62,5 \mu \mathrm{g} / \mathrm{ml}$ dan $31.25 \mu \mathrm{g} / \mathrm{ml}$. Aktivitas antioksidan pada fraksi n-heksan memiliki aktivitas antioksidan sangat lemah dengan IC50 yaitu 312,1238 $\mu \mathrm{g} / \mathrm{ml}$ dan fraksi klorofom memiliki aktivitas antioksidan sedang dengan IC50 yaitu 100,9470 $\mu \mathrm{g} / \mathrm{ml}$. Aktivitas antioksidan dengan katagori sangat kuat di tunjukkan oleh fraksi etil asetat dengan konsentrasi $100 \mu \mathrm{g} / \mathrm{ml}, 50 \mu \mathrm{g} / \mathrm{ml}, 25 \mu \mathrm{g} / \mathrm{ml}, 12,5 \mu \mathrm{g} / \mathrm{ml}, 6,25 \mu \mathrm{g} / \mathrm{ml}$ dan $3,125 \mu \mathrm{g} / \mathrm{ml}$ dengan didapatkan nilai IC50 yaitu $12,1876 \mu \mathrm{g} / \mathrm{ml}$.
\end{abstract}

Kata kunci : Pometia pinnata, aktivitas antioksidan, DPPH, etil asetat 


\section{Pendahuluan}

Antioksidan adalah senyawa yang dapat menetralkan radikal bebas dengan cara menerima atau mendonorkan satu elektron untuk menghilangkan kondisi"elektron tidak berpasangan pada radikal bebas". Hal ini berarti bahwa dalam peroses menetralkan molekul radikal bebas menjadi molekul stabil (tidak stabil), molekul antioksidan tersebut akan menjadi radikal [1].

Antioksidan alamiah merupakan suatu sistem pertahanan dalam tubuh yang berguna untuk menangkal kerusakan sel yang disebabkan oleh radikal bebas. Masalah akan muncul ketika jumlah radikal bebas lebih tinggi dari pada antioksidan alamiah. Pada kondisi ini, tubuh memerlukan tambahan antioksidan dari luar yaitu dari bahan makanan tertentu [2]. Vitamin C juga salah satu jenis vitamin yang mampu menangkal radikal bebas ekstraseluler dengan karakteristik sangat mudah teroksidasi oleh panas, cahaya dan logam [2].

Sejauh ini, yang terkenal dari tanaman matoa adalah buahnya dengan rasa yang khas yang biasanya langsung dikonsumsi. Pada masyarakat lokal, rebusan air daun matoa dipercaya dapat meringankan penyakit hipertensi [2].

\section{Tinjauan Pustaka}

Matoa merupakan salah satu tanaman dari famili sapindaceae yang tersebar di daerah tropis, termasuk Indonesia. Tanaman ini telah di manfaatkan oleh Bangsa Asia (Malaysia dan Indonesia) sebagai salah satu obat-obatan tradisional yang mengandung kelompok senyawa berupa flavanoid, tanin dan saponin [2]. Daun dari tanaman matoa dimanfaatkan sebagai bahan obat oleh masyarakat Talang Mamak di Sekitar Taman Nasional Bukit Tiga puluh, Riau [3]. Manfaat lain, kulit kayu dapat dipakai masyarakat priangan untuk mengobati luka. Di Malaysia, rebusan daun dan kulit kayu dipakai mandi untuk mengatasi demam [4].

Antioksidan adalah substansi yang diperlukan tubuh untuk menetralisir radikal bebas dan mencegah kerusakan yang ditimbulkan terhadap sel normal, protein dan lemak. Antioksidan menstabilkan radikal bebas dengan melengkapi kekurangan elektron, dan menghambat terjadinya reaksi berantai dari pembentukan radikal bebas yang dapat menimbulkan stress oksidatif [5]. Fungsi utama antioksidan adalah melawan (menetralisir) prooksidan atau lebih dikenal sebagai radikal bebas. Antioksidan mampu menghambat proses penuaan organ tubuh, mencegah penyakit jantung, mencegah kanker, mencegah kebutaan, serta meningkatkan sistem kekebalan tubuh [6].

\section{Metode Penelitian}

\subsection{Alat dan Bahan}

Alat yang digunakan pada penelitian ini adalah, beaker glas, rotary evaporator, pipet volum, pipet ukur, pipet mikro, corong pisah, microplate reader tirstar 1941, well plate.

Bahan yang digunakan pada penelitian ini adalah daun matoa (Pometia pinnata J.R \& G. Forst) etanol, metanol, n-heksan, klorofom, etil asetat larutan DPPH, dan vitamin C.

\subsection{Persiapan Sampel}

Ekstraksi Daun matoa (Pometia pinnata J.R \& G. Forst) segar dicuci dengan bersih kemudian dirajang, lalu dikeringkan pada suhu ruangan $\left( \pm 25^{\circ} \mathrm{C}\right)$ hingga kering. Setelah kering simplisia dihaluskan kemudian dilanjutkan proses ekstraksi.

\subsection{Ekstraksi}

Sampel ditimbang sebanyak 50g, kemudian dimaserasi menggunakan 500ml etanol 80\% selama 3 hari sambil sesekali diaduk dan disaring dengan kertas saring, sehingga didapatkan filtrat 1 (F1), filtrat 2 (F2), dan filtrat 3 (F3) digabungkan, kemudian pelarut diuapkan menggunakan rotary evaporator dengan suhu $50^{\circ} \mathrm{C}$ hingga didapatkan ekstrak kental [7].

\subsection{Fraksinasi}

Sebanyak $200 \mathrm{mg}$ ekstrak kental daun matoa (Pometia pinnata J.R \& G. Forst) dilarutkan dengan aquades $100 \mathrm{ml}$ didekantasi selama 2x24 jam dan disaring menggunakan kertas saring whatman. Larutan air kemudian difraksinasi menggunakan $30 \mathrm{ml}$ pelarut dilakukan dengan 3x pengulangan 
yaitu n-heksan, klorofom, dan etil asetat. Hasil pemisahan kemudian diuapkan hingga didapatkan ekstrak kental [8].

3.5 Pembuatan Larutan Induk Sampel

Sebanyak $8 \mathrm{mg}$ sampel dilarutkan dalam $8 \mathrm{ml}$ metanol, sehingga diperoleh larutan induk ekstrak daun matoa (Pometia pinnata J.R \& G. Forst) dengan konsentrasi 1000

$\mu \mathrm{g} / \mathrm{ml}$. Selanjutnya dilakukan pengenceran dengan konsentrasi $500 \mu \mathrm{g} / \mathrm{ml}, 250 \mu \mathrm{g} / \mathrm{ml}, 125 \mu \mathrm{g} / \mathrm{ml}, 62,5$ $\mu \mathrm{g} / \mathrm{ml}$ dan $31,25 \mu \mathrm{g} / \mathrm{ml}$.

3.6 Pembuatan Larutan DPPH $80 \mu \mathrm{g} / \mathrm{ml}$

Larutan DPPH $1000 \mu \mathrm{g} / \mathrm{ml}$ dipersiapkan dengan cara melarutkan $2 \mathrm{mg}$ DPPH dalam $2 \mathrm{ml}$ etanol, kemudian diencerkan dengan melarutkan $0,8 \mathrm{ml}$ larutan dalam 9,2 $\mathrm{ml}$ etanol hingga didapatkan konsentrasi $80 \mu \mathrm{g} / \mathrm{ml}$.

3.7 Pembuatann Larutan Pembanding (Vitamin C)

Vitamin C ditimbang sebanyak 4,4 mg, dilarutkan dengan metanol di dalam vial sebanyak 4,4 ml. Maka didapatkan konsentrasi larutan pembanding $1000 \mu \mathrm{g} / \mathrm{ml}$. Lakukan pengenceran dengan konsentrasi konsentrasi $100 \mu \mathrm{g} / \mathrm{ml}, 50 \mu \mathrm{g} / \mathrm{ml}, 25 \mu \mathrm{g} / \mathrm{ml}, 12,5 \mu \mathrm{g} / \mathrm{ml}, 6,25 \mu \mathrm{g} / \mathrm{ml}$, dan 3,125 $\mu \mathrm{g} / \mathrm{ml}$.

3.8 Uji Aktivitas Antioksidan Fraksi n-hexan, Kloroform dan etil asetat daun matoa (Pometia pinnata J.R \& G. Forst)

Baris A dan B dimasukkan sampel sebanyak $50 \mu \mathrm{L}$ (plate terdiri dari baris A-H masing-masing berjumlah 12 sumur). Sebanyak $50 \mu \mathrm{L}$ metanol dimasukkan pada masing-masing sumur pada baris B-F. Baris A dipipet sebanyak $50 \mu \mathrm{L}$ dan dimasukkan ke baris B, baris B dipipet $50 \mu \mathrm{L}$ dimasukkan ke baris $\mathrm{C}$ dan dilakukan sampai baris $\mathrm{F}$, baris $\mathrm{F}$ dipipet $50 \mu \mathrm{L}$ lalu dibuang, sehingga diperoleh konsentrasi $1000 \mu \mathrm{g} / \mathrm{ml}, 500 \mu \mathrm{g} / \mathrm{ml}, 250 \mu \mathrm{g} / \mathrm{ml}, 125 \mu \mathrm{g} / \mathrm{ml}, 62,5 \mu \mathrm{g} / \mathrm{ml}$, dan 31,25 $\mu \mathrm{g} / \mathrm{ml}$.

Sedangkan pada baris G-H diisi dengan Metanol $50 \mu \mathrm{L}$, khusus pada baris $\mathrm{H}$ diisi hanya sumur 1-6. Baris A-G ditambahkan DPPH sebanyak $80 \mu \mathrm{L}$ dengan konsentrasi $80 \mu \mathrm{g} / \mathrm{mL}$, kemudian diinkubasi selama 30 menit. Kontrol positif yang digunakan sebagai pembanding yaitu vitamin $\mathrm{C}$ dengan konsentrasi $100 \mu \mathrm{g} / \mathrm{ml}, 50 \mu \mathrm{g} / \mathrm{ml}, 25$

$\mu \mathrm{g} / \mathrm{ml}, 12,5 \mu \mathrm{g} / \mathrm{ml}, 6,25 \mu \mathrm{g} / \mathrm{ml}$, dan 3,125 $\mu \mathrm{g} / \mathrm{ml}$. Aktivitas pengkapan radikal diukur sebagai penurunan absorbansi DPPH dengan microplate reader [9].

\subsection{Analisa Data}

Analisis data yang dilakukan pada uji aktivitas antioksidan ekstrak etanol daun matoa (Pometia pinnata J.R \& G. Forst) berdasarkan perhitungan persentase inhibisi serapan radikal DPPH dan nilai IC50 dari persamaan regresi linier.

\section{Hasil dan Pembahasan}

Pengujian aktivitas antioksidan daun matoa dari masing-masing fraksi tersebut dilakukan dengan metode DPPH. DPPH merupakan suatu molekul radikal bebas dengan warna ungu dapat berubah menjadi senyawa yang stabil dengan warna kuning oleh reaksi dengan antioksidan. Dimana antioksidan memberikaan satu elektronnya pada DPPH sehingga terjadi peredaman radikal bebas DPPH. Metode ini yang dipilih mudah untuk menapis sejumlah molekul antioksidan karena reaksi dapat diamati secara visual [10]. DPPH adalah suatu senyawa organik yang mengandung nitrogen tidak stabil dengan absorban pada panjang gelombang maksimum $520 \mathrm{~nm}$ dan berwarna ungu gelap Adanya aktivitas antioksidan dari sampel mengakibatkan perubahan warna pada larutan DPPH yang semula berwarna ungu pekat menjadi kuning pucat hingga tidak berwarna. Berkurangnya intensitas warna ungu dari larutan DPPH dapat menunjukkan bahwa terjadi reaksi antara atom hidrogen yang dilepaskan oleh sampel uji dengan molekul radikal DPPH sehingga terbentuk senyawa1,1-difenil-2- pikrihidrazil yang berwarna kuning [11]. Pada penenlitian ini panjang gelombang maksimum yang dapat digunakan adalah $520 \mathrm{~nm}$ karena panjang gelombang DPPH yang tertinggi adalah $520 \mathrm{~nm}$.

Pengukuran aktivitas antioksidan tersebut dilakukan dengan enam konsentrasi yaitu $1000 \mu \mathrm{g} / \mathrm{ml}$, $500 \mu \mathrm{g} / \mathrm{ml}, 250 \mu \mathrm{g} / \mathrm{ml}, 125 \mu \mathrm{g} / \mathrm{ml}, 62,5 \mu \mathrm{g} / \mathrm{ml}$ dan $31.25 \mu \mathrm{g} / \mathrm{ml}$. Tetapi pada fraksi etil asetat menggunakan konsetrasi $100 \mu \mathrm{g} / \mathrm{ml}, 50 \mu \mathrm{g} / \mathrm{ml}, 25 \mu \mathrm{g} / \mathrm{ml}, 12,5 \mu \mathrm{g} / \mathrm{ml}, 6,25 \mu \mathrm{g} / \mathrm{ml}$ dan $3.125 \mu \mathrm{g} / \mathrm{ml}$ karena pada konsentrasi $1000 \mu \mathrm{g} / \mathrm{ml}$ dan seterusnya nilai IC50 tidak terbaca oleh alat microplate reader. Pada pengujian aktivitas antioksidan vitamin $\mathrm{C}$ sebagai pembanding atau kontrol positif. Vitamin $\mathrm{C}$ digunakan sebagai pembanding karena merupakan salah satu sumber antioksidan yang larut dalam air, mudah diperoleh, dan banyak dikonsumsi masyarakat. Vitamin $\mathrm{C}$ mudah mengalami oksidasi oleh radikal bebas 
karena mempunyai ikatan rangkap dan dengan adanya 2 gugus-OH yang terikat pada ikatan rangkap tersebut, radikal bebas akan mencabut atom hidogen dan menyebabkan muatan negatif pada atom oksigen yang selanjutnya akan terstabilkan melalui resonansi, sehingga menghasilkan radikal bebas yang stabil dan tidak membahayakan [12]. Vitamin $\mathrm{C}$ yang berfungsi sebagai antioksidan dengan cara menangkap radikal bebas dan mencegah terjadinya reaksi berantai [13].

Besarnya suatu aktivitas antioksidan tersebut ditandai dengan nilai IC50 (Inhibition Concentration) semakin kecil nilai IC50 maka aktivitas antioksidannya semakin tinggi. Nilai IC50 diperoleh dari persamaan regresi linier dengan (x) sebagai konsentrasi sampel, dan (y) adalah persen aktivitas antioksidan (\%inhibisi).

Dari pengujian yang telah dilakukan terhadap antioksidan ekstrak daun matoa dengan menggunakan fraksi n-heksan, klorofom dan etil asetat. Masing-masing fraksi dari persamaan regresi linier diperoleh nilai IC50 n-heksan adalah 312,1238 $\mu \mathrm{g} / \mathrm{ml}$, klorofom 100,9470 $\mu \mathrm{g} / \mathrm{ml}$, etil asetat 12,1876 $\mu \mathrm{g} / \mathrm{ml}$ dan nilai IC50 vitamin C sebesar 6,5793 $\mu \mathrm{g} / \mathrm{ml}$. Pada aktivitas antioksidan daun matoa dengan menggunakan fraksi memiliki aktivitas antioksidan sangat kuat yaitu pada fraksi etil asetat dengan nilai IC50 sebesar 12,1876 $\mu \mathrm{g} / \mathrm{ml}$, kemudian pada fraksi klorofom memiliki aktivitas antioksidan sedang yaitu dengan nilai IC50 sebesar $100,9470 \mu \mathrm{g} / \mathrm{ml}$ dan pada fraksi $\mathrm{n}$ - heksan memiliki aktivitas antioksidan sangat lemah yaitu dengan nilai IC50 sebesar 312,1238 $\mu \mathrm{g} / \mathrm{ml}$. pada vitamin C memiliki aktivitas antioksidan sangat kuat dengan nilai IC50 sebesar $6,5793 \mu \mathrm{g} / \mathrm{ml}$.

\section{Kesimpulan}

Berdasarkan hasil penelitian yang telah dilakukan dapat disimpulkan bahwa daun matoa memiliki aktivitas antioksidan yang baik terhadap radikal DPPH. Pada fraksi n- heksan memilki aktivitas antioksidan sangat lemah dengan nilai IC50 312,1238 $\mu \mathrm{g} / \mathrm{ml}$, pada fraksi klorofom memiliki aktivitas antioksidan sedang dengan nilai IC50 100,9470 $\mu \mathrm{g} / \mathrm{ml}$ dan fraksi etil asetat memiliki aktivitas antioksidan sangat kuat dengan nilai IC50 $12,1876 \mu \mathrm{g} / \mathrm{ml}$. Aktivitas antiokisdan dengan kategori sangat kuat di tunjukkan oleh fraksi etil asetat.

\section{REFERENSI}

[1] Muchtadi, D. 2013. Aktivitas Antioksidan \& Kiat Sehat Di Usia Produktif. Bandung :Alfabeta

[2] Martiningsih, N. W., Widana, G. A. B., Kristiyanti, P. L. P.2016. Skrining Fitokimia dan Uji Aktivitas Antioksidan Ekstrak Etanol Daun Matoa(Pometia pinnata) Dengan Metode DPPH, Prosiding Seminar Nasional : 332-338

[3] Setyowati, F.M. dan Wardah. 2007. "Keanekaragaman Tumbuhan Obat Masyarakat Talang Mamak di sekitar Taman Nasional Bukit Tigapuluh, Riau:. Biodiversitas. Volume 8 (3): 228-232

[4] Tanjung, R. H. R., Suharno. 2011. Matoa (Pometia sp). Potendi, Domestifikasi, dan Pembudidayaannya. Cetakan Pertama, Yogyakarta : Pustaka Pelajar

[5] Yunitasari, L. 2011. Gempur 41 Penyakit dengan Buah Maggis , Khasiat dan Cara Pengolahanya untuk Pengobatan. Yogyakarta : Pustaka Baru Press

[6] Paramawati, R. 2010. Dahsyatnya Manggis untuk Menumpas Penyakit. Jakarta : Agromedia

[7] Rivai, H., Nurdin, H., Suyani, H., Bakhtiar, A. 2010. Pengaruh Cara Pengeringan Terhadap Perolehan Ekstraktif, Kadar Senyawa Fenolat dan Aktivitas Antioksidan dari Daun Dewa (Gynura pseudochina (L.) DC.). Jurnal Majalah Obat Tradisional, Volume 15 (1) : 26-33

[8] Kumar, V., Sharma, N., Sourirajan. A., Khosa, P. K. 2017. Comparative evaluation of antimicrobial and antioxidant potential of ethanplic extract and its fractions of bark and leaves of Terminalia arjuna from north-western Himayas, India.1-7.Almurdani, M., Jose, 
C., Teruna, H. Y. 2013. Uji Aktivitas Antioksidan Dan Toksisitas Ekstrak Akar Tanaman Amaranthus Spinosus. J. Ind Che Acta Vol. 4(1) : 7-11

[9] Almurdani, M., Jose, C., Teruna, H. Y. 2013. Uji Aktivitas Antioksidan Dan Toksisitas Ekstrak Akar Tanaman Amaranthus Spinosus. J. Ind Che Acta Vol. 4(1) : 7-11

[10] Yuhernita, J. 2011. Analisis Senyawa Metabolit Sekunder Dari Ekstrak Metanol Daun Surian Yang Berpotensi Sebagai Antioksidan. Makara Sains. Volume 15 (1): 48- 52

[11] Molyneux, P. 2004. The use of the stable free radical diphenylpicrylhydrazyl (DPPH) for estimating antioxidant activity. Sci. Technol. Volume. 26 (2) : 211-219

[12] Cholisoh, Z dan Utami, W. 2008. Aktivitas Penangkap Radikal Ekstrak Etanol 70\% Biji Jengkol (Archidendron jiringa). Pharmacon. Volume 1 (9) : 33-40

[13] Hazimah, H. Y. T. dan Cristie, J. 2013. Aktivitas Antioksidan dan Antimikrobioligi dari ekstrak Plectranhus amboinicus. jurnal Penelitian Farmasi Indonesia. Volume 1 (2): 3942

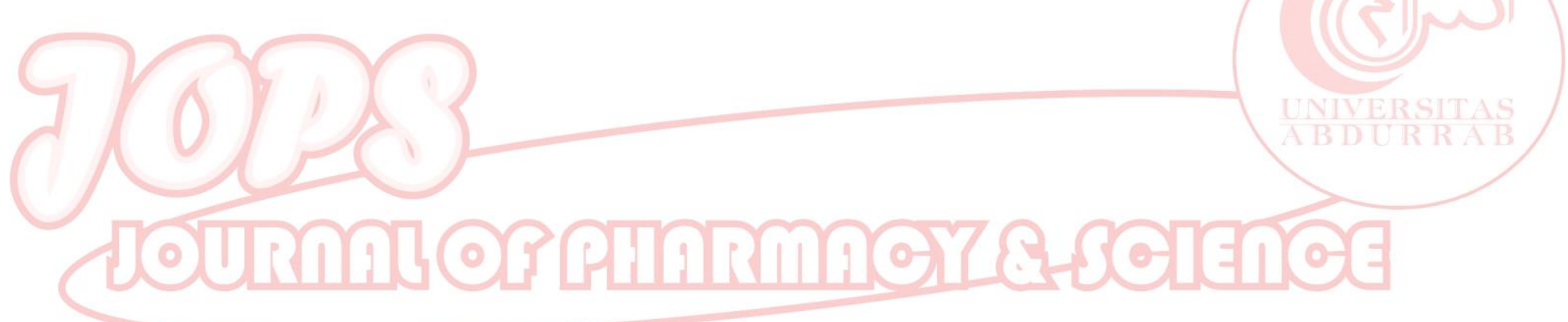

